\title{
Развој јавне библиотеке као отвореног простора у дигиталној ери и њена улога у демократизацији друштва
}

\author{
Јелена Цуца \\ Градска библиотека Вршац \\ jelena.angelovski@gmail.com
}

\begin{abstract}
Сажетак
У времену дигиталних медија, када су информације лако доступне, јавне библиотеке имају, више него икада, обавезу да корисницима омогуће инфраструктуру за отворени дискурс и да дигитализацијом обезбеде библиотечку грађу која није доступна на интернету. Неопходно је да узму активно учешће у изградњи социјалног капитала и „изборе“ се за примарно место у дигиталном друштву. Да би привукле грађане и постале простор за развој демократског друштва, потребно је да дефинишу на који начин дигитализација мења њихову улогу и да нађу начин за квалитетније коришћење информационокомуникационих технологија и доступних текућих и ретроспективних организованих ресурса. Потребно је дефинисати проблеме и потребе корисника, а затим прегледом и анализирањем теорија и коришћењем примера добре праксе створити јавни простор где они могу да изражавају и размењују своја мишљења, знања и идеје и тиме допринесу изградњи демократије.
\end{abstract}

Кључне речи: јавне библиотеке, дигитализација, јавни дискурс, социјални капитал, демократија, социјални утицај

Увод

Посматрана са аспекта функције очувања грађанског, демократског друштва, као и темеља на којем почива културноисторијски и научни развој заједнице, библиотека новог доба поставља пред нас следеће питање како дигитализација мења улогу јавних библиотека као инфраструктуре за отворени дискурс.

У IFLA/UNESCO Манифесӣу о јавним библиоеиекама из 1994. каже се да су слобода, просперитет и развој друштва и појединаца основне људске вредности које ће се остварити путем способности добро информисаних грађана да остварују своја демократска права и да играју активну улогу у друштву. Такође, наводи се да јавна библиотека представља основни услов за доживотно учење, самостално доношење одлука и културни развој индивидуалних и друштвених група. ${ }^{1}$

Према Бушману, јавне библиотеке, стварањем доступних текућих и ретроспективних организованих ресурса, пружају могућност провере информација које леже у основама закона, правилника, теза и других докумената и на тај начин настављају дебату и процес пропитивања који леже у срцу јавне сфере и демократије. ${ }^{2}$

Питер Брофи наводи да „постоје многе, веома цењене улоге које библиотеке могу обављати у XXI веку, али ће најмоћнија бити улога 'информационог посредника унутар заједнице',

\footnotetext{
${ }^{1}$ IFLA, "IFLA/ UNESCO Public library manifesto", IFLA, https://www.ifla.org/publications/iflaunesco-public-library-manifesto-1994 (preuzeto 27. 8. 2017).

2 John Buschman, "On Libraries and the Public Sphere", Library Philosophy and Practice (e-journal) 11 (2005), http://digitalcommons.unl. edu/cgi/viewcontent.cgi?article=1010\&context=libphilprac (preuzeto 27. 8. 2017)
} 
тела које разуме и уме да се поистовети са заједницом својих корисника, добро познаје универзум информација и његову организацију, и истовремено развија и побољшава механизме који повезују та два света". ${ }^{3}$

Из наведеног се може јасно видети да је развој информационог друштва и демократије довео до раста одговорности јавне библиотеке.

\section{Библиотеке у дигиталном добу}

Како живимо у дигиталној ери, где извори информација утичу на свакодневни живот грађана, чини се да је, више него раније, потребно објаснити која је улога јавних библиотека, као институција које их похрањују, у изградњи отвореног јавног дискурса. Да би привукле кориснике да их посете и постале простор за развој демократског друштва, потребно је да дефинишу на који начин дигитализација мења њихову улогу као инфраструктуре за јавни разговор и дебату и да нађу начин за квалитетније коришћење дигиталних ресурса уз учешће корисника.

Када се говори о процесу дигитализације и корисницима библиотечких фондова, постоје два главна питања: како испунити крајњи циљ јавних библиотека, прикупити све расположиве информације и учинити их приступачним за све кориснике? и друго: када се испуни поменути циљ, ко ће осетити потребу да долази у библиотеку када су сви тражени подаци већ у џеповима и торбама корисника у секундама након упита? Свако ново решење у унапређењу рада јавних библиотека носи са собом и нове изазове са којима се треба суочити и створити модерне и доступне институције које прате начин живота својих корисника.

У дигиталној ери, са брзим развојем технологије, када су таблети и мобилни телефони са добрим интернет везама свуда и свакоме доступни, решење је постављање дигиталних колекција на уређаје. Приоритет је довести информације до корисника, где год да се они физички налазе. Јер, како су Горман и Клејтон закључили и посредно дали одговор на друго питање, у дигиталној епохи расте важност вредновања фонда усмереног на кориснике, пошто читаоци више нису ограничени на коришћење само једног физичког фонда. ${ }^{4}$ Очигледно је да је дошло време за нови правац развоја, време за другачију интеракцију са корисницима. Динамика пословања се мења све брже и пожељно је, ако не и неопходно, да јавне библиотеке буду још присутније и активније у заједници и животима грађана. Осим активности које се организују у самој установи, данас је могуће бити присутан и у дигиталној сфери и на услузи корисницима на било који од ова два начина.

Дигитални свет доноси велике могућности када су у питању библиотечки сервиси. Пословање се унапредило и свакодневно се откривају и примењују новине које и библиотекарима и корисницима пружају далеко више могућности него раније. Услуге јесу окренуте ка корисницима, али стално испитивање њихових потреба и жеља данас је од виталног значаја. Није довољно само претпостављати и планирати будуће делање на основу ранијих активности које су биле мање или више успешне. Редовном комуникацијом са корисницима, заинтересованошћу за њих и њихове потребе, јавне библиотеке, поред виртуелног простора, настављају да буду тачка сусрета у заједници. Уколико постоји акција, неминовно ће доћи до реакције. „Понекад, када дате моћ корисницима, они могу да открију новине о вашем производу, као и другачије начине његовог коришћења, на које ви никада не бисте помислили“. ${ }^{5}$ Јавне библиотеке иду у сусрет грађанима, како би они ишли у сусрет библиотекама, дакле, реч је о динамици која иде у оба смера.

\footnotetext{
${ }^{3}$ Piter Brofi, Biblioteka u dvadeset prvom veku (Beograd: Clio, 2005), 241.

${ }^{4}$ Gari Judžin Gorman i Piter Klejton, Upravljanje izvorima informacija u bibliotekama (Beograd: Clio, 2003), 230.

${ }^{5}$ Michael P. Sauers, "Library 2.0: Creating a borderless library", Thinking Outside the Borders (2007): 158, http://www.library.illinois.edu/ mortenson/wp-content/uploads/sites/64/2017/07/TOTB-bookcomplete.pdf (preuzeto 27. 8. 2017).
} 
Чињеница је, такође, да дигитализација мења природу садржаја који се нуде те корисницима треба пружити оне који на интернету нису доступни у облику који би задовољио њихове потребе и знатижељу.

Питање дигитализације истиче се кроз квалитетан избор материјала који ће задовољити потребе корисника. Низ активности може служити овој сврси, а многе јавне библиотеке их већ имају у својим редовним програмима. Реч је о анкетама, упитницима, књигама утисака, онлајн и у самој библиотеци. Тако се може доћи до одговора на питање о материјалу који треба дигитализовати, који ће задовољити потребе корисника и за којим постоји интересовање.

Осим тога, могу се организовати представљања различитих фондова библиотека јавности, јер многи корисници се служе само једним делом фонда, не знајући да постоје и неки други, који би им били интересантни. Улога и дужност библиотекара јесте да укаже корисницима на све изворе информација. Да их упути како да нађу тражено, али и да им препоручи литературу са којом можда нису имали прилике да се до тада сретну. Сваки библиотекар осећа то као посебну сатисфакцију. Коришћењем дигиталног фонда библиотеке корисник понекад пропушта шансу да, самостално или уз помоћ стручног особља, открије нове изворе знања.

\section{Библиотека као место састајања}

Дигитализација неминовно доводи до стварања нових заједница - група истомишљеника, који у виртуелном окружењу међусобно дискутују, размењују стечена знања и искуства, а јавне библиотеке морају да, више него раније, уложе напоре како би утицале на кориснике и остале чланове друштва да се врате у институције и своје мишљење лично поделе са другима.

Спајање људи који деле (или не деле) исто мишљење и имају жељу да о томе разговарају представља важан фактор у развоју социјализације и демократизације, а то је једна од претпоставки за рад јавних библиотека.

Последњих година спроведена су бројна истраживања која су проучавала јавне библиотеке као места за састајање и развој демократске заједнице. ${ }^{6}$ Једно од њих „указује на то да је библиотека комплексно место састајања са низом сусрета дуж континуума од високоинтензивних до нискоинтензивних састанака". ${ }^{7}$

Концепт високоинтензивних састанака подразумева да корисници долазе у јавну библиотеку како би задовољили своја примарна интересовања и разменили мишљење са групама истомишљеника. Уколико, пак, приликом посета библиотеци долазе у контакт са људима заинтересованим за потпуно другачије области - јавна библиотека постаје место нискоинтензивног састанка. Корисници који преусмере своје активности са примарних, као што је на пример заштита животне средине, на нешто друго - само читање дневне штампе у углу читаонице, и то се сматра преусмеравањем са високо на нискоинтензивну активност. ${ }^{8}$ Привући кориснике да чешће посећују библиотеку, посматрано кроз ове концепте, подразумева да особе које долазе због конкретног садржаја буду што чешће у окружењу других, који им могу привући пажњу. Чак и уколико их нешто ново не заинтересује одмах, важно је да буду свесни да имају избор и да им се ту он и нуди. Такође, они који долазе без неког конкретног разлога, дакле на место састанка ниског интензитета, могу бити изложени интересовањима која ће убудуће бити основ

\footnotetext{
${ }^{6}$ Један од најутицајнијих до сада јесте пројекат Јавне библиоиеке - Арене за ірађансйво (PLACE), који је добио средства Норвешког истраживачког савета за период 2007-2011.

${ }^{7}$ Ragnar Audunson et al., "Public libraries, social capital and low intensive meeting places", Information Research 1, 4 (2007), http:// www.informationr.net/ir/12-4/colis/colis20.html (preuzeto 27. 8. 2017).

${ }^{8}$ Ragnar Audunson and Svanhild Aabø, "Use of library space and the library as place", Library and Information Science Research 34, 2 (2012), https://www.researchgate.net/publication/257244923_Use_of_library_space_and_the_library_as_place (preuzeto 27. 8. 2017).
} 
за њихову наредну посету и тиме се интензитет помера на високоинтензивне састанке. И на крају, важно је обезбедити корисницима простор где могу да изразе своје мишљење и на тај начин доприносу својој заједници.

Овај концепт може помоћи у дефинисању активности јавних библиотека које треба усмерити ка налажењу начина да се привуку корисници различите старосне доби, култура, етничке, образовне структуре да чешће посећују библиотеке и да се на тај начин створи отворенија и демократичнија заједница. ${ }^{9}$

\section{Улога библиотеке у изградњи демократског друштва}

Није непознаница да дигитализација представља доминантно кретање које обликује друштво данашњице. Требало би проучити нове активности јавних библиотека уз учешће грађана, као нове изазове у дигиталном добу. На тај начин би се закључило да ли ове активности могу бити довољан разлог за коришћење библиотеке као јавног простора за отворен дијалог и изградњу друштвеног капитала. Она треба да створи атмосферу универзалности, да буде место отворено за свакога, у коме су различита мишљења добродошла. Када је грађани буду доживели на овај начин, прихватиће је као независну и отворену јавну институцију.

Примарни циљ јавних библиотека требало би да буде проучавање и објашњење стварања и развоја установе као неутралне тачке сусретања и јавног дебатовања. „Библиотеке могу изградити друштвени капитал трима различитим стратегијама: директним радом са добровољним организацијама, организовањем неформалних места за састајање и као пружаоци универзалних сервиса за јавност. ${ }^{10}$ Сарадња са различитим удружењима и институцијама представља редовну праксу када је реч о активностима јавних библиотека. Друге две поменуте стратегије јесу присутне, али не толико систематично и доследно. Потребно је активно пратити кретање интересовања и потреба друштва, организовати серије обука, едукативних састанака и радионица који ће привући чланове заједнице да буду активни, да квалитетно проведу своје време и на крају да имају осећај припадности групи и сатисфакцију због свог доприноса.То могу бити радионице о ручним радовима, сликарству, предавања о филателији, историји, школе страних језика или основе коришћења рачунара. У другом сегменту, могу једни друге обучавати, они који добро играју шах, могу своју вештину и знање пренети некоме кога то интересује, а заузврат добити знање из области која их занима, на пример, како користити компјутер. Кроз добро припремљен, посвећено спроведен и касније темељно проучен активизам могуће је доћи до резултата и уједно до јасно искристалисаног пута којим корисници јавних библиотека желе да се оне крећу и на који начин да се развијају.

\section{Закључак}

Анализом активности јавних библиотека и њиховим унапређењем долази се до закључка да су оне од изузетне важности за грађење социјалног капитала, а може се слободно рећи да су данас, из те перспективе, у нашем друштву важније и потребније него икад. Оне морају створити окружење у којем ће чланови заједнице бити изложени разноврсним и инспиративним садржајима који иницирају дијалог и размену мишљења и на тај начин унапредити демократско деловање друштва.

\footnotetext{
9 Добар пример за то је програм промоције књиге и читања „Једна књига, један град“. Видети: Горан Траиловић, „Програм промоци-

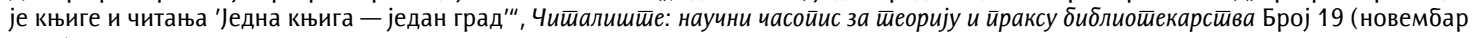
2011): 22-26.

${ }^{10}$ Andreas Vårheim, "Social capital and public libraries: The need for research", Library \& Information Science Research 29, 3 (2007), https://www.researchgate.net/publication/223328845_Social_capital_and_public_libraries_The_need_for_research (preuzeto 27. 8. 2017).
} 
Примећује се велика разноликост у коришћењу библиотечких фондова, као и у профилу корисника библиотека у дигиталној ери. „Корисници библиотека данас имају све сложеније потребе за учењем и информацијама. Технолошки напредак, као што је продор интернет приступа и појављивање мобилних уређаја који имају приступ дигиталном садржају, такође је променио начин на који људи користе информације. Наше библиотеке морају бити физички и дигитално спремне да подрже промену знања и потреба за учењем." 11 Јавна библиотека мора оправдати своју демократску улогу места које је отворено за размену идеја и знања и које даје својој заједници оно што јој треба. Активно праћење потреба друштва и синхроног деловања у складу са њима представљају основ за проактивно пословање јавне библиотеке у служби грађана у дигиталној ери. Уколико се не анализирају истраживања која имају за циљ да предвиде потребе друштва и на тај начин испрате промене, постаће само магацини који чувају знање. Знање, које ће бити похрањено дигитално у неком облаку изнад свих библиотека.

\section{Литература и извори:}

1. Audunson, Ragnar, Andreas Vårheim, Svanhild Aabø and Erling Dokk Holm. "Public libraries, social capital and low intensive meeting places". Information Research 12, 4 (2007). http://www.informationr. net/ir/12-4/colis/colis20.html (preuzeto 27. 8. 2017).

2. Audunson, Ragnar and Svanhild Aabø. "Use of library space and the library as place". Library and Information Science Research 34, 2 (2012). https://www.researchgate.net/publication/257244923_Use_ of_library_space_and_the_library_as_place (preuzeto 27. 8. 2017).

3. Brofi, Piter. Biblioteka u dvadeset prvom veku. Beograd: Clio, 2005.

4. Buschman, John. "On Libraries and the Public Sphere". Library Philosophy and Practice (e-journal) 11 (2005). http://digitalcommons.unl.edu/cgi/viewcontent.cgi?article=1010\&context=libphilprac (preuzeto 27. 8. 2017).

5. Gorman, Gari Judžin i Piter Klejton. Upravljanje izvorima informacija u bibliotekama. Beograd: Clio, 2003.

6. IFLA. "IFLA/ UNESCO Public Library Manifesto". IFLA. https://www.ifla.org/publications/iflaunescopublic-library-manifesto-1994 (preuzeto 27. 8. 2017).

7. Koh, Lynn, Lynnette Kang and Felicia Chan. "Every leader a library, every library its leader: Designing responsive libraries for our community“. Rad predstavljen na IFLA WLIC - Dynamic libraries: Access, Development and Transformation, Kejptaun, Južnoafrička Republika, 15-21. avgust 2015. http:// library.ifla.org/1105/1/075-koh-en.pdf (preuzeto 28. 8. 2017).

8. Sauers, Michael P. "Library 2.0: Creating a borderless library". Thinking Outside the Borders (2007). http://www.library.illinois.edu/mortenson/wp-content/uploads/sites/64/2017/07/TOTBbookcomplete.pdf (preuzeto 27. 8. 2017).

9. Trailović, Goran. „Program promocije knjige i čitanja 'Jedna knjiga - jedan grad'“. Čitalište: naučni časopis za teoriju i praksu bibliotekarstva Broj 19 (novembar 2011): 22-26.

10. Vårheim, Andreas. "Social capital and public libraries: The need for research". Library \& Information Science Research 29, 3 (2007). https://www.researchgate.net/publication/223328845_Social_capital_ and_public_libraries_The_need_for_research (preuzeto 27. 8. 2017).

\footnotetext{
${ }^{11}$ Lynn Koh et al., "Every leader a library, every library its leader: Designing responsive libraries for our community" (rad predstavljen na IFLA WLIC - Dynamic libraries: Access, Development and Transformation, Kejptaun, Južnoafrička Republika, 15-21. avgust 2015), http://library.ifla.org/1105/1/075-koh-en.pdf (preuzeto 28. 8. 2017).
} 


\title{
Development of Public Libraries as Open Spaces in the Digital Era and Their Role in Democratization of Society
}

\begin{abstract}
Summary
With the advent of the digital era, information is more accessible than ever. Libraries must answer the question: How does digitization change the role of libraries as an infrastructure for an open and enlightened public discourse? Digitization brings individualization of the society. Through this process, library gives all the knowledge and information to users, in seconds, wherever they are and whatever device they use. Users do not need to come to the library, thereby depriving a social aspect that implies user contact with librarians and other users. This comfort brings with it a problem: How will the function of the library and the users' attitude change in the context of content digitization and their greater accessibility? This paper presents an analysis of definitions, theories and dominant trends that shape today's movement of society, the concept of social capital, the public sphere, the role of libraries as a meeting place, and the operation of libraries in the era of digitization. The starting assumption is that society moves from socialization towards individualization and libraries have an impact on that flow. Using the comparative and historical, thereby critical methods, the ways in which libraries can actively participate in the development of social capital and take the primary place in a digital society are explored. With the perception of public libraries that have characteristics of places of high and low intensity meetings, the paper offers practical solutions on how to attract as many users as possible to participate actively in the life of a community and democracy building.
\end{abstract}

Keywords: Public libraries, digitization, public discourse, social capital, democracy, social impact

Примљено: 4. септембра 2017

Исправке рукописа: 16. фебруара 2018. Прихваћено за објављивање: 24. фебруара 2018. 


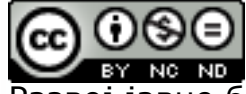

Развој јавне библиотеке као отвореног простора у дигиталној ери и њена улога у демократизацији друштва by Јелена Цуца is licensed under a Creative Commons Attribution-NonCommercial-NoDerivatives 4.0 International License. 